\title{
Agricultural Trade Restrictiveness in the European Union and the United States
}

\author{
Jean-Christophe Bureau and Luca Salvatici
}

Working Paper 01-WP 277

June 2001

\author{
Center for Agricultural and Rural Development \\ lowa State University \\ Ames, lowa 50011-1070 \\ www.card.iastate.edu
}

\begin{abstract}
Jean-Christophe Bureau is a professor at UMR INRA-INAPG Economie Publique, Paris, and a visiting scholar in the Department of Economics and Center for Agricultural and Rural Development at lowa State University. Luca Salvatici is an assistant professor in the Dipartimento di Economia Pubblica, Università "La Sapienza" di Roma.

The authors thank Christian Bach who kindly provided useful samples of some of his GAMS programs, as well as Mark Gehlhar for providing most recent conversion tables between the Harmonised system and GTAP classification. They also thank Alex Gohin and Linda Fulponi for helpful comments. For this research J.C. Bureau and L. Salvatici benefited from financial support under the European FAIR97-CT3481 project, and from a grant of the Italian Ministry of University and Technological Research ("The forthcoming WTO negotiations on agriculture and the reform of the European Union"). Seniority is shared equally between authors.
\end{abstract}

This publication is available online on the CARD website: www.card.iastate.edu. Permission is granted to reproduce this information with appropriate attribution to the authors and the Center for Agricultural and Rural Development, lowa State University, Ames, lowa 50011-1070.

For questions or comments about the contents of this paper, please contact J.C. Bureau, UMR INRA-INAPG Economie publique, BP1, 78860 Grignon, France. E-mail: jbureau@card. iastate.edu (until September 2001); or bureau@grignon.inra.fr. (after September 2001).

lowa State University does not discriminate on the basis of race, color, age, religion, national origin, sexual orientation, sex, marital status, disability, or status as a U.S. Vietnam Era Veteran. Any persons having inquiries concerning this may contact the Director of Affirmative Action, 318 Beardshear Hall, 515-294-7612. 


\begin{abstract}
This paper provides a summary measure of the Uruguay Round tariff reduction commitments in the European Union and the United States, using the Mercantilistic Trade Restrictiveness Index (MTRI) as the tariff aggregator. We compute the index for agricultural commodity aggregates assuming a specific (Constant Elasticity of Substitution) functional form for import demand. The levels of the MTRI under the actual commitments of the Uruguay Round are computed and compared with two hypothetical cases, the Swiss Formula leading to a 36 percent average decrease in tariffs and a uniform 36 percent reduction of each tariff. This makes it possible to infer how reducing tariff dispersion would help improve market access in future trade agreements.
\end{abstract}

Key words: agricultural prices, income, international agricultural trade, policy analysis, tariffs and tariff factors. 


\section{AGRICULTURAL TRADE RESTRICTIVENESS IN THE EUROPEAN UNION AND THE UNITED STATES}

\section{Introduction}

Bureau, Fulponi, and Salvatici (2000), hereafter BFS, addressed the problem of assessing the tariff reduction commitments undertaken by the European Union (EU) and the United States under the Uruguay Round Agreement on Agriculture (URAA). They used the Trade Restrictiveness Index (TRI) and the Mercantilistic Trade Restrictiveness Index (MTRI) in order to solve the tariff index aggregation problem. The TRI, introduced by Anderson and Neary (1996), consists in estimating the uniform tariff that yields the same aggregate utility level as the original tariff structure. The MTRI, introduced by Anderson and Neary (1999), consists in estimating the uniform tariff that yields the same aggregate volume of imports as the original vector of (nonuniform) tariffs across a number of imports. Because we believe that using the trade volume as the reference standard is of particular interest in the context of trade negotiations, we focus on the MTRI in this paper. Indeed, countries involved in the negotiation are interested in the trade volume displacement due to changes in tariffs, perhaps more than on the effect on welfare. Also, one of the pillars of the World Trade Organization (WTO) is the "principle of reciprocity" that can be interpreted as equivalent import volume expansion (see Bagwell and Staiger 2000).

Because of data limitation and the lack of a general equilibrium model, BFS followed a "local approach." That is, they estimated the rates of change of the TRI and MTRI between the year 1995 (the first year of the implementation of the URAA) and the year 2000 (the end of the implementation period) rather than the level of TRI and MTRI. This made it possible to assess the impact of the tariff reductions agreed upon during the Uruguay Round. BFS also compared the effect of the Uruguay Round agreement on tariffs with two counterfactual scenarios. The first one is an alternative tariff reduction scheme called the "Swiss Formula," whereby high tariffs are cut more dramatically than low tariffs, resulting in the reduction of 
tariff dispersion. The second scenario is a uniform (i.e., radial) reduction in tariffs in the case of both the European Union and the United States. ${ }^{1}$

Based on the same data set on tariffs and imports, this paper intends to alleviate some of the limitations of the "local approach" followed by BFS in assessing the restrictiveness of the U.S. and EU agricultural trade policy. First, in terms of policy analysis, we compute the level of MTRI and not simply the relative rates of change between two points in time. That is, we are able to make more meaningful comparisons of trade restrictiveness across countries. Indeed, rates of change in the MTRI between two time periods give a partial image of the degree of trade liberalization, because larger reductions are easier to achieve in countries where the initial tariff structure is more distorting. By measuring the absolute MTRI level at two points in time, our results provide not only a measure of the effect of the URAA but also a measure of the overall level of protection across countries, both before and after the Uruguay Round.

Second, while BFS only estimated changes in market access for the aggregate set of agricultural and food products covered by the URAA, we also provide indicators of the level market access for 20 subaggregates. The 20 aggregate commodities are consistent with a data set that is widely used by trade practitioners, the Global Trade Analysis Project data set (Hertel 1997).

Third, the approach followed by BFS requires estimating a very large number of import elasticities. This raises a lot of computational difficulties. BFS estimated these elasticities econometrically under very restrictive assumptions. They assumed, in particular, that the matrix of price elasticities of imports was diagonal. Here, we follow an approach that does not require estimating import elasticities for each individual commodity. However, the toll is the need to specify a tariff aggregator function, here a constant elasticity import demand, which also requires restrictive assumptions.

\section{Methodology}

The practical and theoretical deficiencies of traditional tariff indexes, such as the simple or the trade-weighted average tariff, are well known (Laird and Yeats 1988; Anderson and Neary 1999). Indexes such as the TRI and the MTRI have more solid theo- 
retical foundations, although the definition of such indexes relies on several restrictive assumptions, including the existence of a competitive equilibrium, a single representative consumer, and fixed world prices (i.e., the small country assumption). Because they are derived from the balance of trade function, the TRI and the MTRI synthesize the overall effect of trade policy on the economy. ${ }^{2}$

The authors who estimated the MTRI used a computable general equilibrium (CGE) model (see Anderson and Neary 1999). Such a model makes it possible to compute the MTRI as the (scalar) tariff that would yield the same volume of imports as the initial tariff structure. However, most CGE models are built on a restricted list of commodities. ${ }^{3}$ This requires a substantial aggregation of trade flows and tariffs. However, agricultural tariffs vary widely within a single product aggregate (e.g., within a single chapter of the Harmonized System or HS classification of the United Nations). In addition, tariff reductions under the URAA were taken on the basis of a very detailed list of items, and the magnitude of tariff cut also varies substantially within a product category (Gibson et al. 2001). Therefore, a significant amount of information on the level of tariff dispersion (and on the change in dispersion over time) is lost when aggregating tariffs data up to the level that is consistent with CGE models aggregates. In order to be able to take into account the impacts of changes occurring on a very large number of finely differentiated tariff lines, we build on the insights of Bach and Martin (2001) who assume a specific functional for import demand. Their methodology, which aims to develop tariff aggregators for both the expenditure and tariff revenue components of CGE models, can be adapted in order to compute the MTRI.

\section{Mercantilistic Trade Restrictiveness Index}

The MTRI relies on the idea of evaluating trade policy using trade volume as the reference standard (Anderson and Neary 1999). The MTRI is defined in terms of the uniform tariff $\tau$ which yields the same volume (at world prices) of tariff-restricted imports as the initial vector of (nonuniform) tariffs. This can be expressed with import demand functions $M$, while holding constant the balance-of-trade function at level $B^{0}$ :

$$
\tau: M\left[(1+\tau) p^{*}, B^{0}\right]=M^{0}
$$


where $p^{*}$ denotes the international price vector of the $N$ goods $k=(1, \ldots, N)$ and $M^{0}$ is the value of aggregate imports (at world prices) in the reference period. Define the scalar import demand as

$$
M\left(p, p^{*}, B\right) \equiv \sum_{k=1}^{N} p_{k}^{*} I_{k}^{m}
$$

where $I^{m}$ denotes the uncompensated (Marshallian) import demand function and $p$ is the domestic price vector. Accordingly, the MTRI-uniform tariff $t$ would lead to the same volume of imports (at world prices) as the one resulting from the uneven tariff structure, denoted by the $N$-dimensional tariff vector $t$ whose elements are $t_{k}$. That is,

$$
\sum_{k=1}^{N} p_{k}^{*} I_{k}^{m}\left[p^{*}(1+\tau), B^{0}\right]=\sum_{k=1}^{N} p_{k}^{*} I_{k}^{m}\left[p^{*}(1+t), B^{0}\right]
$$

The MTRI can be computed by solving equation (3) for $t$.

The MTRI derived from equation (3) provides a measure of trade restrictiveness relative to a free trade reference. If we want to compare our results with those obtained by BFS, who measured changes between two protected situations, we need to be consistent with their "local approach." This means that we need to focus on the change in the tariff structure from the initial equilibrium corresponding to the price vector $p^{0}=p^{*}\left(1+t^{0}\right)$ and the new (still distorted) equilibrium corresponding to the price vector $p^{1}=p^{*}\left(1+t^{1}\right)$, rather than focusing on free trade. Following Anderson and Neary (1999), we can then define the "uniform tariff surcharge" $\mu$ which, when applied to the prices in the new equilibrium $p^{l}$, yields the same volume (at world prices) of tariffrestricted imports as the old equilibrium $M^{0}$. Formally,

$$
\mu: M\left[(1+\mu) p^{1}, B^{0}\right]=M^{0}=M\left(p^{0}, B^{0}\right) .
$$

\section{Empirical Estimation of the MTRI}

Having defined the MTRI, for the empirical implementation we model demand through a Constant Elasticity of Substitution (CES) functional form. This function im- 
poses restrictive assumptions on separability. This function is nevertheless widely used in the CGE literature (Hertel, Ianchivichina, and McDonald 1997).

We assume that the overall basket of goods can be partitioned into $J$ aggregates denoted $j=1, \ldots J$. This requires that the utility function of the representative consumer is separable, so that it can be written as a sum of $J$ functions $\phi_{j}$ :

$$
U(x)=\sum_{j} \phi_{j}\left(u_{j}\left(x_{j}\right)\right)
$$

That is, the overall utility function $U$ is built up from lower level subutility function $u_{j}$. Each vector $x_{j}$ containts $N_{j}$ elements. We assume that $u_{j}$ is a CES function in $x_{j}$. We use the popular Armington (1969) assumption that imports are imperfect substitutes of domestic goods. We partition the consumption vector $x_{j}$ within the $j$ th group into an aggregated domestic good denoted with a suffix $d$ and $N_{j}-1$ traded goods denoted with an index $i$.

$$
u_{j}(x)=\left(b_{d j}\left(x_{d j}\right)^{\rho_{j}}+\sum_{i} b_{i j}\left(x_{i j}\right)^{\rho_{j}}\right)^{\frac{1}{\rho_{j}}}, i=1, \ldots N_{j} .
$$

Denoting $\sigma_{j}=\frac{1}{1-\rho_{j}}$ the elasticity of substitution within the $j$ group, the expenditure devoted to each aggregate $j$, is

$$
e_{j}(p, u)=\left(\beta_{d j}\left(p_{d j}\right)^{1-\sigma_{j}}+\sum_{i} \beta_{i j}\left(p_{i j}\right)^{1-\sigma_{j}}\right)^{\frac{1}{1-\sigma_{j}}} u_{j} .
$$

The parameters $\beta_{i j}$ can be calibrated to the initial values of the expenditure shares in the base data, when all domestic prices are set to 1 . After deriving the indirect utility function by inverting equation (7), the demand functions of each of the $i=1, . ., N_{j}-1$ imported goods can be found by Roy's identity:

$$
x_{i j}=\beta_{i j} \frac{p_{i j}^{-\sigma_{j}}}{\left(\beta_{d j}\left(p_{d j}\right)^{1-\sigma_{j}}+\sum_{i} \beta_{i j}\left(p_{i j}\right)^{1-\sigma_{j}}\right)} e_{j} .
$$


Denoting $P_{j}$ the price index that corresponds to the denominator of the right-hand side, the import volume function for the $j$ th aggregate, valued at world prices, is

$$
\sum_{i=1}^{N^{j}} p_{i j}^{*} x_{i j}=\sum_{i} p_{i j}^{*} \beta_{i j}\left(\frac{1}{P_{j} \cdot p_{i j}^{\sigma_{j}}}\right) e_{j} \text { with } i=1, \ldots, N_{j}-1 \text {. }
$$

When the initial total expenditure $e_{j}^{0}$ (expenditures on both domestic and imports in $j$ ) is used in expression (9), we obtain the demand function at the initial level of imports. Because the import volume function is homogenous of degree zero in the prices of all traded goods, it does not make sense to define trade restrictiveness without selecting an untaxed good as a reference. ${ }^{4}$ As in Bach and Martin (2001), we solve the problem by taking the domestic good as a numéraire.

The MTRI-uniform tariff equivalent $\tau_{j}$ for each aggregate $j$ is found by setting the value of the import volume function with the uniform tariff equivalent equal to the initial value of imports (evaluated at world prices), ${ }^{5}$

$$
\sum_{i} p_{i j}^{*} \beta_{i j}\left(\frac{P_{j}^{\tau}}{p_{i j}^{*}\left(1+\tau_{j}\right)}\right)^{\sigma_{j}} e_{j}^{0}=\sum_{i} p_{i j}^{*} I_{i j}^{0}
$$

where $I_{i j}^{0}$ are the volume of imports in the initial period (i.e., 1995 or 2000 in our numerical applications), and $P_{j}^{\tau}$ is the price index:

$$
P_{j}^{\tau}=\left(\beta_{d j}\left(p_{d j}\right)^{1-\sigma_{j}}+\sum_{i} \beta_{i j}\left(p_{i j}^{*}\left(1+\tau_{j}\right)\right)^{1-\sigma_{j}}\right)^{-\sigma_{j}} .
$$

The uniform tariff equivalents for each aggregate commodity $j$ are found using an optimization routine in the GAMS package (Brooke et al. 1998), solving for $\tau_{j}$ in equations (10) and (11).

The indicators $\tau_{j}$ are by themselves relevant for the analysis of trade policy. In addition, the $\tau_{j}$ can be used as aggregate tariffs in any trade model with a commodity aggregation and an import demand structure which is consistent with our assumptions. ${ }^{6}$ However, rather than using a full CGE model, we can readily compute an overall MTRI $\tau$ 
that corresponds to the uniform tariff that would keep the overall (i.e., on all $j=1, \ldots, N$ sectors) import volume equal to the initial value. This can be obtained by modifying equation (10) as follows:

$$
\sum_{j} \sum_{i} p_{i j}^{*} \beta_{i j}\left(\frac{\left(\beta_{d j}\left(p_{d j}\right)^{1-\sigma_{j}}+\sum_{i} \beta_{i j}\left(p_{i j}^{*}(1+\tau)\right)^{1-\sigma_{j}}\right)^{-\sigma_{j}}}{p_{i j}^{*}(1+\tau)}\right)^{\sigma_{j}} e_{j}^{0}=\sum_{j} \sum_{i} p_{i j}^{*} I_{i j}^{0} .
$$

In the same vein, the overall MTRI-uniform tariff factor surcharge can be obtained by solving for $\mu$ in equation (13):

$$
\sum_{j} \sum_{i} p_{i j}^{*} \beta_{i j}\left(\frac{\left(\beta_{d j}\left(p_{d j}\right)^{1-\sigma_{j}}+\sum_{i} \beta_{i j}\left(p_{i j}^{1}(1+\mu)\right)^{1-\sigma_{j}}\right)^{-\sigma_{j}}}{p_{i j}^{1}(1+\mu)}\right)^{\sigma_{j}} e_{j}^{0}=\sum_{j} \sum_{i} p_{i j}^{*} I_{i j}^{0} .
$$

\section{Data Set}

The world prices are the average unit values of imports (CIF) over the 1994-96 period. The volumes of imports are taken directly from the respective U.S. and EU data sets (U.S. International Trade Commission and Eurostat's Comext data set). The Schedule XX that the European Union and the United States submitted to the WTO provides the base and bound tariffs at the 8-digit level of the HS classification. The URAA schedule therefore provides information on tariffs in 1995 (that is, after the Uruguay Round tariffication process) and in 2000 (that is, after the implementation of the mandatory 36 percent average reduction in tariffs). The domestic prices are constructed by multiplying the world price $\mathrm{p}^{*}$ by the ad valorem tariff structure (initial, final, or counterfactual tariffs) that we are interested in. As a result, the measure of market access focuses only on changes in the tariffs ceteris paribus and is not affected by exogenous price variations (see BFS 2000 for details on the data set). 
The EU-15 tariff reduction commitments cover 1,764 tariff lines, while the U.S. schedule includes 1,377 tariff lines. Both the European Union and the United States apply their bound tariffs on products traded in a Most Favored Nation (MFN) framework. That is, using the URAA schedules as a source of information on tariffs gives a good image of the actual tariff structure, although lower tariffs are applied in the framework of preferential agreements that we did not consider here. For purposes of calculation, we converted specific tariffs into ad valorem equivalents, following the same conventions as in BFS (2000).

The data on the total expenditure are taken from the Global Trade Analysis Project (GTAP) version 4 data set (McDougall, Elbehri, and Truong 1998). This comprehensive data set is widely used in applied analysis, and researchers might be interested in tariff aggregates that match the GTAP classification for simulation purposes. Moreover, the conversion tables from detailed tariff structures (HS 8-digit) to the GTAP sectors are fully available, which makes it possible to aggregate the very detailed list of tariffs of the URAA Schedule into a restricted number of products that correspond to the GTAP system of classification. Finally, the data set provides the information that is necessary for distinguishing between expenditures on domestic products imports for the various aggregates and also provides elasticities of substitution $\sigma_{j}$ that match the list of aggregates.

The original GTAP data set distinguishes $J=20$ agricultural and food aggregate products. In order to include nonfood other commodities listed in the URAA schedules (mainly agricultural goods listed in chapters 25 to 53 of the HS classification) we defined an extra aggregate, which does not exist in the original GTAP classification (see Table 1). We ignore one GTAP sector (raw milk) because there is no trade for the corresponding commodity. Overall, we aggregated 1,764 tariff lines in the European Union (1,377 tariff lines in the United States) at the 8-digit level of the HS classification up to 20 aggregate products described in Table 1. It is noteworthy that the number of tariff lines in each commodity aggregate is very uneven. Table 1 shows, for example, that there are only three tariff lines in the aggregate "paddy rice," while the aggregate "fruits and vegetable" tariff includes 183 tariff lines listed in the EU schedule. 
TABLE 1. GTAP agricultural commodities and HS-8 tariff lines

\begin{tabular}{|c|c|c|c|}
\hline Commodities $^{\text {a }}$ & $\begin{array}{c}\text { GTAP } \\
\text { Classification }\end{array}$ & $\begin{array}{c}\text { Number of } \\
\text { Tariff Lines, } \\
\text { EU }\end{array}$ & $\begin{array}{c}\text { Number of } \\
\text { Tariff Lines, } \\
\text { U.S. }\end{array}$ \\
\hline Paddy rice & 1 & 3 & 3 \\
\hline Wheat & 2 & 3 & 3 \\
\hline Cereal grains & 3 & 13 & 12 \\
\hline Vegetables, fruits, nuts & 4 & 183 & 186 \\
\hline Oilseeds & 5 & 31 & 16 \\
\hline Sugar cane, sugar beet & 6 & 3 & 2 \\
\hline Plant-based fibers & 7 & 4 & 7 \\
\hline Other crops & 8 & 111 & 116 \\
\hline Cattle, sheep, goats, horses & 9 & 14 & 12 \\
\hline Other animal products & 10 & 73 & 50 \\
\hline Raw wool, cocoons, and hair & 12 & 9 & 17 \\
\hline Meat: cattle, sheep, goats, horses & 19 & 77 & 34 \\
\hline Other meat products & 20 & 199 & 61 \\
\hline Vegetable oils and fats & 21 & 112 & 70 \\
\hline Dairy products & 22 & 121 & 118 \\
\hline Processed rice & 23 & 2 & 3 \\
\hline Sugar & 24 & 10 & 15 \\
\hline Other food products & 25 & 580 & 489 \\
\hline Beverages and tobacco & 26 & 87 & 84 \\
\hline Nonfood items (goods listed in & & & \\
\hline URAA, beyond Chapter HS 24) & Other & 130 & 79 \\
\hline
\end{tabular}

${ }^{a}$ Raw milk (GTAP code 20) is excluded because of absence of trade.

\section{The Measure of Market Access Prior to the Uruguay Round Agreement}

The computation of the MTRI-uniform tariff equivalent $\tau_{j}$ provides an estimate of the trade restrictiveness of the actual tariff structure. It is calculated for the year 1995 for both the European Union and the United States, making it possible to compare the trade effect of EU and U.S. tariff structure prior to implementation of the Uruguay Round commitments. The structure of bound tariffs in the European Union and the United States differs in several aspects.

Table 2 shows that three product categories in the European Union face zero tariffs (oilseeds, fibres, wool) while all aggregates tariffs in the United States face a strictly 
TABLE 2. Base tariffs (year 1995, actual bound tariffs)

\begin{tabular}{|c|c|c|c|c|c|c|c|c|}
\hline \multirow[t]{2}{*}{ Commodities } & \multicolumn{2}{|c|}{$\begin{array}{c}\text { Nonweighted } \\
\text { Average } \\
\text { Tariff (\%) } \\
\end{array}$} & \multicolumn{2}{|c|}{$\begin{array}{c}\text { Trade- } \\
\text { Weighted } \\
\text { Average } \\
\text { Tariff }(\%)\end{array}$} & \multicolumn{2}{|c|}{$\begin{array}{c}\text { MTRI Tariff } \\
(\%)\end{array}$} & \multicolumn{2}{|c|}{$\begin{array}{c}\text { Coefficient of } \\
\text { Variation of } \\
\text { Tariffs } \\
\end{array}$} \\
\hline & $\mathrm{EU}$ & US & EU & US & $\mathrm{EU}$ & US & EU & US \\
\hline Paddy rice & 58.6 & 3.0 & 80.5 & 1.7 & 80.8 & 1.7 & 0.70 & 0.53 \\
\hline Wheat & 57.8 & 4.9 & 114.0 & 4.5 & 114.0 & 4.5 & 0.86 & 0.27 \\
\hline Cereal grains & 45.6 & 1.1 & 84.4 & 0.8 & 89.8 & 0.8 & 0.97 & 1.00 \\
\hline Vegetables, fruits, nuts & 16.8 & 6.9 & 57.5 & 4.2 & 68.9 & 4.5 & 1.28 & 1.21 \\
\hline Oilseeds & 0 & 23.6 & 0 & 4.0 & 0 & 6.6 & 0 & 2.51 \\
\hline Sugar cane, sugar beet & 40.3 & 2.9 & 14.2 & 3.7 & 14.8 & 3.7 & 1.02 & 0.40 \\
\hline Plant-based fibers & 0 & 11.1 & 0 & 2.8 & 0 & 2.9 & 0 & 0.87 \\
\hline Other crops & 7.5 & 3.7 & 7.8 & 1.7 & 8.0 & 1.8 & 0.93 & 2.49 \\
\hline $\begin{array}{l}\text { Cattle, sheep, goats, } \\
\text { horses }\end{array}$ & 30.2 & 2.1 & 36.2 & 0.1 & 51.5 & 0.1 & 1.52 & 2.36 \\
\hline Other animal products & 4.9 & 1.1 & 2.2 & 0.3 & 2.6 & 0.3 & 1.99 & 2.12 \\
\hline Raw wool, cocoons, hair & 0.1 & 3.5 & 0 & 5.4 & 0 & 5.4 & 0 & 1.15 \\
\hline $\begin{array}{l}\text { Meat: cattle, sheep, } \\
\text { goats, horses }\end{array}$ & 62.1 & 7.0 & 94.0 & 1.1 & 103.2 & 1.1 & 1.02 & 1.67 \\
\hline Other meat products & 35.1 & 4.8 & 24.7 & 1.9 & 26.4 & 2.0 & 1.06 & 0.93 \\
\hline Vegetable oils and fats & 14.5 & 4.5 & 5.7 & 3.1 & 6.8 & 3.1 & 1.54 & 1.15 \\
\hline Dairy products & 72.0 & 26.5 & 69.7 & 8.1 & 76.4 & 11.4 & 0.83 & 1.06 \\
\hline Processed rice & 99.2 & 7.8 & 126.4 & 3.4 & 127.6 & 3.4 & 0.52 & 1.08 \\
\hline Sugar & 39.2 & 26.0 & 63.9 & 13.9 & 67.5 & 15.2 & 0.91 & 1.20 \\
\hline Other food products & 28.0 & 11.8 & 19.7 & 5.6 & 23.7 & 6.0 & 1.02 & 1.71 \\
\hline Beverages and tobacco & 15.8 & 7.2 & 28.2 & 2.3 & 36.7 & 2.4 & 1.51 & 1.24 \\
\hline Nonfood items & 8.6 & 3.0 & 3.6 & 2.1 & 3.7 & 2.1 & 1.38 & 1.20 \\
\hline
\end{tabular}

Note: All three tariff indices compare the actual tariff structure with free trade. See text for details.

positive average tariff. However, this mainly reflects the particular structure of the GTAP classification. Overall, the original 1995 EU tariff schedule included 245 lines with zero tariffs, while the U.S. schedule included 303 lines with zero tariffs. The average nonweighted base tariff was 9.7 percent (12.7 percent if we focus only on the items with a nonzero tariff) in the United States, while in the European Union the average tariffs were 26.7 percent (31.4 percent, respectively). ${ }^{7}$

In most sectors, the EU average tariff is larger than the U.S. average tariff, the gap being particularly wide in the grains, meat, sugar, and rice sectors. It is worth noting, though, that in the European Union the trade-weighted average tariff is usually larger 
than the nonweighted average, while it is generally the opposite in the United States. A trade-weighted average tariff that is smaller than the nonweighted one can result from prohibitive tariffs or may simply mean that larger tariffs are set on commodities whose demand is particularly elastic. This suggests that higher tariffs are set on sensitive products, in the sense that the government is willing to protect domestic production from imports, as is the case in the U.S. dairy sector. On the other hand, the trade-weighted average is larger than the nonweighted average tariff when low tariffs are set on products whose demand is structurally limited, either because these are niche market products (e.g., processed products, peculiar types of fruits, beverages, and condiments in the European Union), or because local producers are competitive (e.g., pig meat and poultry meat in the European Union). This may also mean that higher tariffs are set on goods with a relatively inelastic demand for imports. This is typically the case in the European Union, in the beef, sugar, and grain sectors.

\section{Comparisons between the MTRI and A-Theoretic Indicators}

Table 2 shows significant differences between the MTRI and the nonweighted tariff average. This is not surprising, since the nonweighted tariff average bears little relationship with theoretically sound indexes like the MTRI or the TRI.

On the other hand, the values for the trade-weighted average tariffs are often quite close to those given by the MTRI tariff. This empirical finding converges with those of Anderson and Neary (1999) and Bach and Martin (2001) who show that the trade-weighted average tariff is a linear approximation to the tariff aggregator based on the expenditure function. In other terms, the trade-weighted average tariff plays the same role as the Laspeyres price index in consumer theory, providing a fixed-weight approximation that underestimates the "true" height of tariffs because it neglects substitution induced by tariff changes.

This empirical finding can be explored a bit further in the particular case of a CES aggregator function, where the trade-weighted average tariff corresponds to constant expenditure shares. Constant shares correspond to the special case of a Cobb-Douglas subutility function, where $\sigma_{j}=1$. In such a case, we have the following result (proof of all propositions are given in the Appendix). 
PROPOSITION 1. In the base equilibrium (that is, with all domestic prices equal to 1), the MTRI-uniform tariff coincides with the trade-weighted average tariff when the CES aggregator function becomes Cobb-Douglas.

This proposition clarifies the linkage between our MTRI estimates, using a CES aggregator function, and the trade-weighted index. Since the values of the $\sigma_{j}$ in the GTAP data set rank between 2.2. and 3.8, it is not surprising that the MTRI for the aggregate level is sometimes close to the value of the trade-weighted average tariff.

The MTRI-uniform tariff is more likely to be higher than the trade-weighted average tariff the more elastic is the demand for tariff-constrained imports. On the basis of empirical calculations with a CGE model, Anderson and Neary (1999) are able to confirm this basic insight, and our empirical use of the MTRI in order to construct sectoral tariff aggregates leads to similar conclusions. ${ }^{8}$ In our specific case of a CES aggregator function, we can derive more explicitly the conditions under which the MTRI exceeds the trade-weighted index:

PROPOSITION 2. In the base equilibrium (that is, with all domestic prices equal to 1), (i) the trade-weighted average tariff overestimates the MTRI-uniform tariff when $\sigma<1$ ( $\sigma$ denotes the elasticity of substitution of the CES aggregator function); (ii) the tradeweighted average tariff underestimates the MTRI-uniform tariff when $\sigma>1$.

Looking at Tables 1 and 2, it is also obvious that the MTRI and the trade-weighted index give very similar results when the number of tariff lines in the aggregate is very small, or when there is little dispersion in tariffs within an aggregate. Figures in Table 2 show that the percentage variation between the MTRI and the trade-weighted average depends positively on the standard error of tariffs, something that is confirmed by elementary descriptive statistics. For the aggregates with a large number of products, the gap between the two indexes can be very large. In the dairy sector, for example, the tradeweighted average underestimates the trade restrictiveness of the pre-URAA tariff structure by 29 percent in the United States and by 9 percent in the European Union. This is also the case in the cattle sector and in the beverages sector in the European Union (underestimation of 29 percent and 23 percent respectively), and in the oilseeds sector in the United States 
(underestimation of 40 percent). Overall, for six aggregate EU products out of twenty, the trade-weighted average underestimates the MTRI by more than 10 percent.

In brief, the trade-weighted tariff can only be a satisfactory approximation of more theoretically consistent indicators of market access under very specific conditions and for specific values of the substitution elasticities. In more general cases, when the aggregate includes a large number of heterogeneous tariff lines that differ from unity, the tradeweighted average is a poor indicator of the restrictiveness of the tariff structure.

\section{The Impact of the Uruguay Round and Counterfactual Scenarios}

The computation of the MTRI for the year 2000 makes it possible to evaluate the trade restrictiveness of the tariff structure that results from the URAA. Following BFS, we also want to assess the relative effects of reducing the tariff average and tariff dispersion. We simulated two other tariff reduction schemes in addition to the actual reduction implemented by the European Union and the United States. The three cases are called Uruguay Round commitments, Swiss Formula, and uniform tariff reduction. In the three cases, we start from the same tariff structure in 1995 (that is, the initial vector $p_{i}^{95}$ is the same for each case), but the three schemes lead to three different $p_{i}^{2000}$ vectors. These may be summarized as follows:

- Uruguay Round commitments. The price vector $p^{2000}$ is the one that results from the bound tariffs in year 2000. The resulting tariff structure reflects the obligation of a 36 percent nonweighted average reduction, but with no constraints placed on the mix of reductions to achieve the overall average (except that each tariff line must be reduced by at least 15 percent).

- Swiss Formula. In this case, we calculate the price vector $p^{2000}$ that would have resulted from a tariff reduction for which higher tariffs would have been subject to larger cuts. The "Swiss Formula" is given in equation (14) and the parameter $\mathrm{C}$ is chosen to obtain the same nonweighted average reduction of 36 percent in tariffs as specified in the URAA. Comparing the value of the MTRI-uniform tariff equivalents with those that actually result from URAA commitments, we can 
assess the impact of commitments that would have focused more on reducing tariff dispersion than the actual Urugay Round tariff cuts.

$$
t_{i}^{2000}=C t_{i}^{1995} /\left(C+t_{i}^{1995}\right) .
$$

- Uniform tariff reduction. Under this scheme, we assume that a uniform 36 percent reduction is applied to all tariff lines. This will obviously result in the same average reduction as specified under the URAA, but it does not permit countries to allocate the adjustment across commodities. The comparison of the values of the MTRI-uniform tariff equivalents with those that actually result from URAA commitments therefore measures the magnitude of the "dilution effect" that resulted from the distribution of large and small or minimal cuts across tariff lines.

Comparing the values of the MTRI-uniform tariff equivalents of the 2000 tariffs (first column in Table 3) with the MTRI-uniform tariff equivalents of the 1995 tariffs (third column in Table 2), we can assess the actual impact of the URAA in terms of market access. The URAA had an impact in terms of the reduction of each of the 20 MTRI-uniform tariffs both in the European Union and in the United States (see Figures 1 and 2).

Because both the variance and the mean of tariffs decrease (see Tables 4 and 5), it is not surprising that the MTRI-uniform tariff also moves in the same direction for all aggregates, as well as at the aggregate level, confirming that the URAA increased market access. This is a consequence of the commitment to reduce each tariff line by at least 15 percent.

The absolute values of the reductions are much smaller in the case of the United States, as could have been expected given the low values of the MTRI-uniform tariff equivalents in the base period (see Table 2). This is also consistent with the BFS results suggesting that the Uruguay Round led to a larger increase in market access in the European Union than in the United States.

We now turn to the counterfactual scenarios in Table 3. Overall, the results show that the various ways of cutting tariffs only have a very limited impact on the overall access to the U.S. market, due to the low levels of tariffs in the first place. If the Swiss Formula had 
TABLE 3. MTRI-uniform tariff equivalents (\%) in year 2000: actual bound tariffs and counterfactual scenarios

\begin{tabular}{|c|c|c|c|c|c|c|}
\hline \multirow[b]{2}{*}{ Commodities } & \multicolumn{2}{|c|}{$\begin{array}{l}\text { Uruguay Round } \\
\text { Commitments }\end{array}$} & \multicolumn{2}{|c|}{ Swiss Formula } & \multicolumn{2}{|c|}{$\begin{array}{l}\text { Uniform } 36 \% \\
\text { Tariff Reduction }\end{array}$} \\
\hline & $\mathbf{E U}$ & U.S. & $\mathbf{E U}$ & U.S. & $\mathbf{E U}$ & U.S. \\
\hline Paddy rice & 51.9 & 1.1 & 23.9 & 1.5 & 52.0 & 1.1 \\
\hline Wheat & 73.0 & 2.9 & 26.2 & 3.3 & 73.0 & 2.9 \\
\hline Cereal grains & 59.9 & 0.5 & 24.1 & 0.7 & 60.7 & 0.5 \\
\hline Vegetables, fruits, nuts & 58.1 & 3.0 & 21.5 & 2.3 & 51.6 & 3.0 \\
\hline Oilseeds & 0.0 & 5.5 & 0 & 2.1 & 0 & 5.5 \\
\hline Sugar cane, sugar beet & 12.0 & 2.3 & 9.5 & 2.8 & 9.8 & 2.3 \\
\hline Plant based fibers & 0 & 1.9 & 0 & 1.9 & 0 & 1.9 \\
\hline Other crops & 3.4 & 1.2 & 6.0 & 1.0 & 5.3 & 1.2 \\
\hline $\begin{array}{l}\text { Cattle, sheep, goats, } \\
\text { horses }\end{array}$ & 38.9 & 0.1 & 18.8 & 0.1 & 39.4 & 0.1 \\
\hline Other animal products & 1.9 & 0.2 & 1.8 & 0.2 & 1.9 & 0.2 \\
\hline Raw wool, cocoons, hair & 0 & 3.5 & 0 & 3.6 & 0 & 3.5 \\
\hline $\begin{array}{l}\text { Meat: cattle, sheep, } \\
\text { goats, horses }\end{array}$ & 70.5 & 0.7 & 24.9 & 0.8 & 70.7 & 0.7 \\
\hline Other meat products & 17.5 & 1.3 & 13.6 & 1.4 & 17.9 & 1.3 \\
\hline Vegetable oils and fats & 5.3 & 2.1 & 4.2 & 2.1 & 4.9 & 2.1 \\
\hline Dairy products & 53.0 & 9.0 & 23.0 & 3.0 & 52.1 & 9.0 \\
\hline Processed rice & 82.3 & 2.2 & 26.9 & 2.6 & 82.3 & 2.2 \\
\hline Sugar & 55.3 & 10.4 & 21.9 & 5.5 & 45.2 & 10.4 \\
\hline Other food products & 18.7 & 4.0 & 12.6 & 3.0 & 17.1 & 4.0 \\
\hline Beverages and tobacco & 25.4 & 1.6 & 16.4 & 1.8 & 27.0 & 1.6 \\
\hline Nonfood items & 1.4 & 1.4 & 3.0 & 1.4 & 2.4 & 1.4 \\
\hline
\end{tabular}

Note: All three scenarios compare a counterfactual tariff structure with free trade. See text for details.

been applied, the Uruguay Round would have led to a considerable increase in market access as measured by the MTRI. In the European Union, the Swiss Formula would have led to a dramatic decrease in trade restrictions in highly protected sectors such as grains, meat, and dairy, as well as in sectors characterized by a high tariff dispersion, such as fruits and vegetables. The U.S. market also would have been more open at the aggregate level (see Table 4), but there are quite a few instances (e.g., rice, cereals, sugar, meat) where the Swiss Formula does not perform better than the uniform tariff reduction (or even the URAA), while this never happens in the case of the European Union.

Tables 3, 4, and 5 show that the URAA has increased access to the market in a way that is very comparable to what would have resulted from a uniform tariff reduction in 


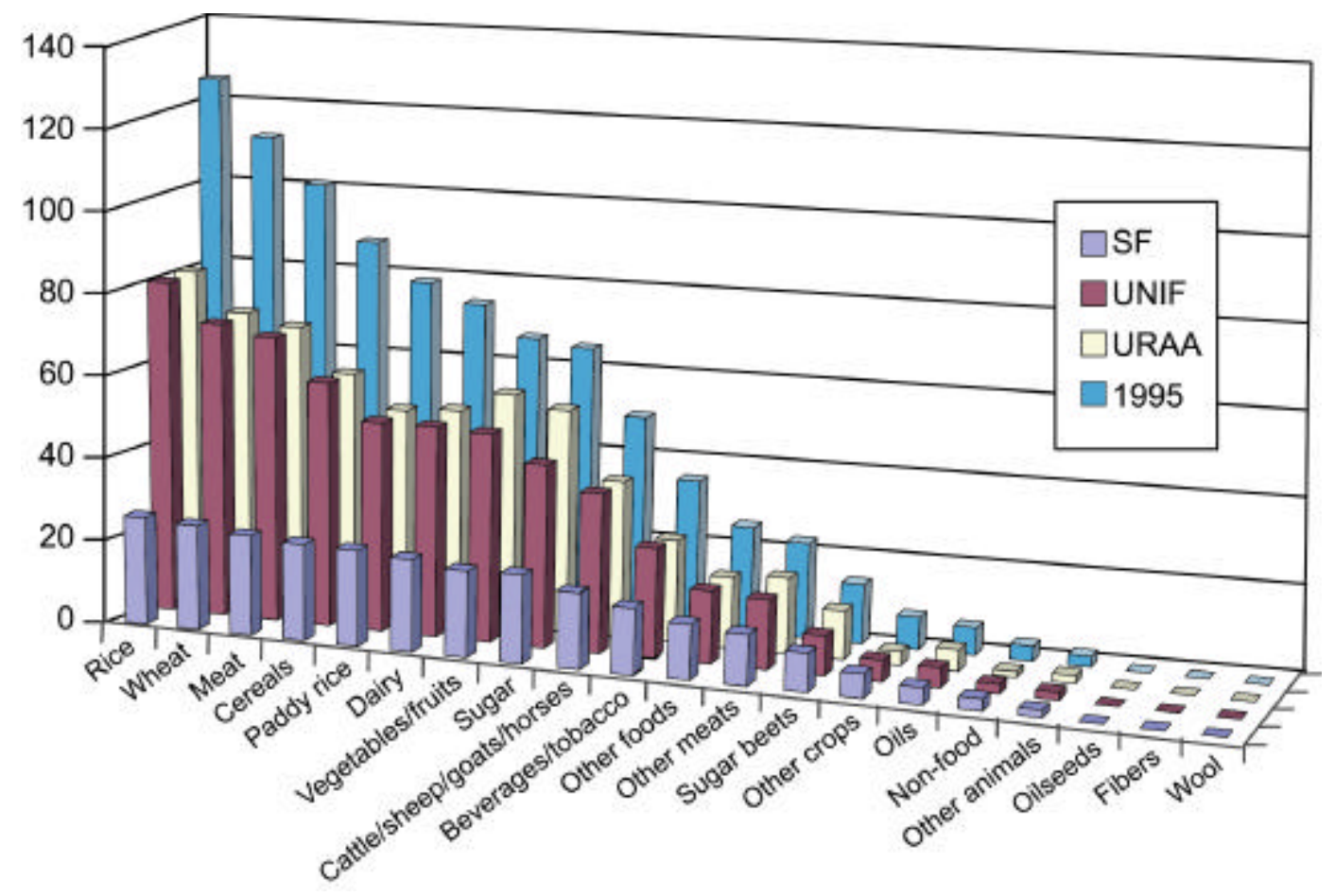

FIGURE 1. MTRI-uniform tariffs for the European Union

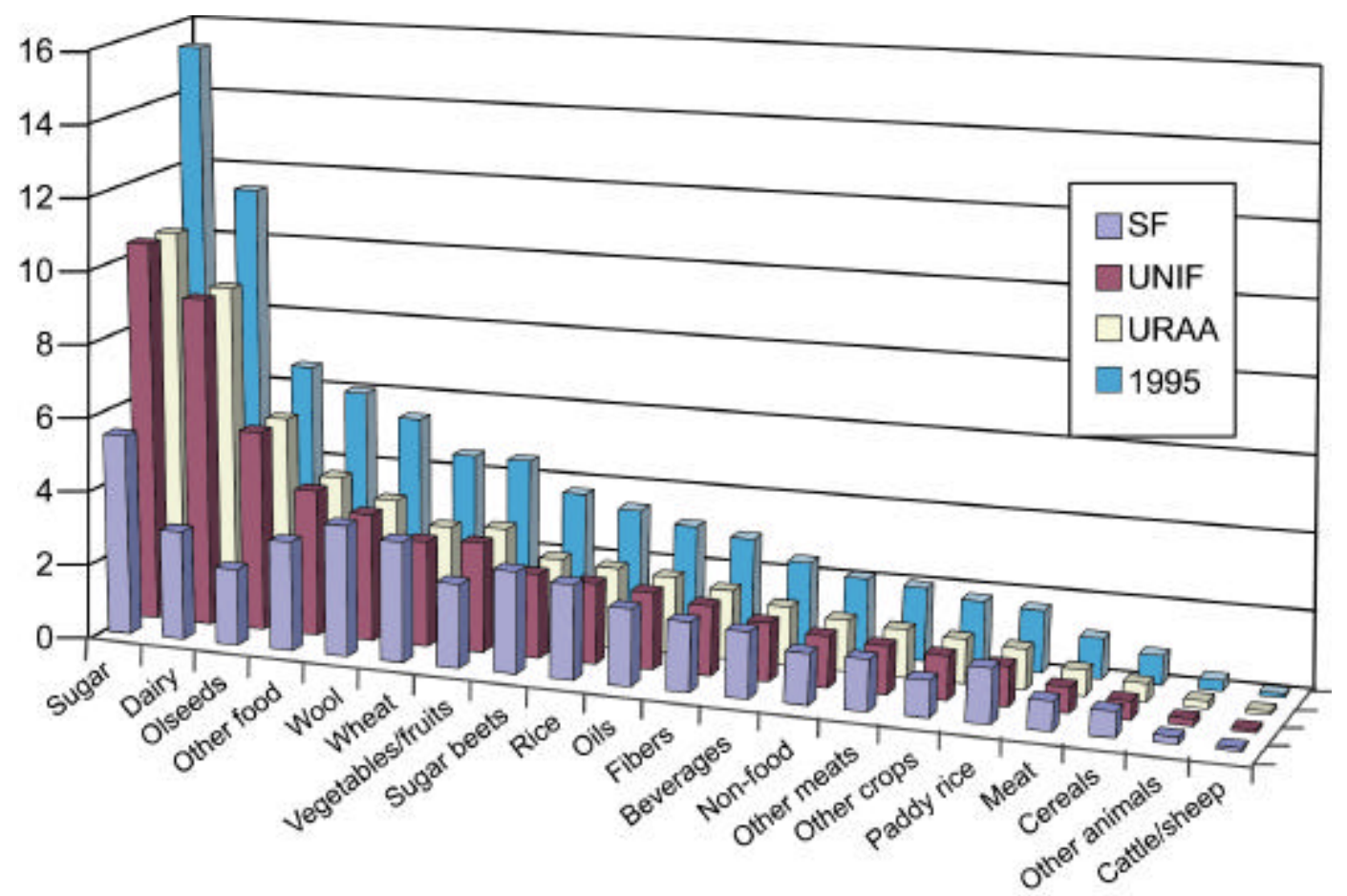

FIGURE 2. MTRI-uniform tariffs for the United States 
TABLE 4. United States aggregate results

\begin{tabular}{lcccc}
\hline $\begin{array}{l}\text { Tariff Structures } \\
\text { (Ad Valorem Equiva- } \\
\text { lent, in Percentage) }\end{array}$ & $\begin{array}{c}\text { Standard } \\
\text { Deviation }\end{array}$ & Mean* & $\begin{array}{c}\text { MTRI- } \\
\text { uniform } \\
\text { Tariff }\end{array}$ & $\begin{array}{c}\text { Trade- } \\
\text { Weighted } \\
\text { Tariff Mean }\end{array}$ \\
\hline $\begin{array}{l}\text { Base rates (year 1995) } \\
\text { Bound rates UR commit- } \\
\text { ments (year 2000) }\end{array}$ & 18.3 & 9.7 & 3.5 & 3.3 \\
$\begin{array}{c}\text { Swiss Formula scenario } \\
\quad \text { year 2000) }\end{array}$ & 15.5 & 7.1 & 2.4 & $2.2^{* *}$ \\
$\begin{array}{c}\text { Uniform reduction } \\
\text { scenario (year 2000) }\end{array}$ & 11.7 & 3.5 & 1.9 & $1.7^{* *}$ \\
\hline
\end{tabular}

Note: * nonweighted arithmetic mean; ** weighted by 1995 import values.

TABLE 5. European Union aggregate results

\begin{tabular}{lcccc}
\hline $\begin{array}{l}\text { Tariff Structures } \\
\text { (Ad Aalorem Equiva- } \\
\text { lent, in Percentage) }\end{array}$ & $\begin{array}{c}\text { Standard } \\
\text { Deviation }\end{array}$ & Mean* $^{\text {MTRI- }}$ & $\begin{array}{c}\text { Trade- } \\
\text { uniform } \\
\text { Tariff }\end{array}$ & $\begin{array}{c}\text { Weighted } \\
\text { Tariff Mean }\end{array}$ \\
\hline $\begin{array}{l}\text { Base rates (year 1995) } \\
\text { Bound rates UR commit- } \\
\text { ments (year 2000) }\end{array}$ & 38.6 & 26.7 & 32.4 & 25.5 \\
$\begin{array}{c}\text { Swiss Formula scenario } \\
\quad \text { year 2000) }\end{array}$ & 26.8 & 17.9 & 25.6 & $17.8^{* *}$ \\
$\begin{array}{c}\text { Uniform reduction } \\
\text { scenario (year 2000) }\end{array}$ & 7.8 & 11.1 & 13.4 & $8.4^{* *}$ \\
\hline
\end{tabular}

Note: * nonweighted arithmetic mean; **weighted by 1995 import values.

most sectors. This means that both countries have not allocated tariff cuts in a very "strategic" way. The results also confirm the finding that the "dilution" of the tariff reduction effect was limited in the European Union, as could have been expected since most tariffs were cut by 36 percent and no tariff was reduced by less than 20 percent. However, if we compare the ranking of sectors according to the MTRI-uniform tariff level in 1995 with the ranking resulting after the URAA implementation, there is evidence of a more "strategic" allocation of tariff cuts by the European Union. Figures 1 and 2 show that there is only one change in the United States (other food products trading places with raw wool), while there are quite a few changes in the European Union, where fruits and vegetables and sugar gain positions, while dairy products and other crops move down in the ranking.

\section{Comparison with Previous Results and Sensitivity}


The comparison of the MTRI-uniform tariff equivalents between the URAA commitments and the counterfactual scenarios confirms BFS's conclusions that the dilution of tariff cuts has had overall a limited impact on market access in the two countries. It also confirms that the Swiss Formula would have resulted in much larger market access than that which occurs with the Uruguay Round discipline in the European Union. However, if we want to check the consistency of the numerical results with those of BFS, we need to turn to the MTRI-uniform tariff surcharges as indicated in equation (4). The results for the aggregate agricultural and food products are presented in Table 6.

Given the differences in the methodological approaches followed here and in BFS (2000), the results are surprisingly similar. Only in the case of the Swiss Formula is the difference substantial, especially in the case of the European Union. This is the scenario that implies the largest change in tariffs; in such a case, then, the higher substitutability implied by the CES functional form leads to a higher impact. ${ }^{9}$

Finally, since our results are based on unsophisticated estimates of substitution elasticities (the ones taken out of the GTAP data set), it is necessary to ask to what extent these may affect the MTRI computation. In Table 7, we compute the overall MTRIuniform tariff equivalents, making different assumptions about the values of the substitution elasticities. The elasticities are assumed to range from one-third to three times the original values.

Even though the ranking among different scenarios remains the same for the various elasticities assumptions, the MTRI is obviously quite sensitive to the degree of substitution between products, a result consistent with Proposition 2. Since the large

TABLE 6. Comparisons of MTRI-uniform tariff surcharges with BFS rates of change (absolute values)

\begin{tabular}{lccccccc}
\hline & \multicolumn{3}{c}{ European Union } & & \multicolumn{3}{c}{ United States } \\
\cline { 2 - 3 } \cline { 6 - 7 } & Uruguay & Swiss & Uniform & & Uruguay & Swiss & Uniform \\
\hline$\mu$ & 5.4 & 16.8 & 6.2 & & 1.0 & 1.3 & 1.0 \\
$\mathrm{BFS}$ & 5.7 & 10.6 & 6.3 & & 1.0 & 1.1 & 1.0 \\
\hline
\end{tabular}

Note: All tariff indices compare the initial (1995) tariff structure with the new (2000) ones. See text for details. 
TABLE 7. Sensitivity of MTRI-uniform tariff to a change in the elasticities of substitution

\begin{tabular}{|c|c|c|c|c|c|c|c|c|}
\hline & \multicolumn{4}{|c|}{ European Union } & \multicolumn{4}{|c|}{ United States } \\
\hline & Base & Uruguay & Swiss & Uniform & Base & Uruguay & Swiss & Uniform \\
\hline $0.3 * \sigma_{j}$ & 26.0 & 17.4 & 9.3 & 16.6 & 3.1 & 2.1 & 1.8 & 2.1 \\
\hline $1.3{ }^{*} \sigma_{j}$ & 36.5 & 29.0 & 14.9 & 28.0 & 3.6 & 2.6 & 2.0 & 2.5 \\
\hline $2^{*} \sigma_{j}$ & 45.5 & 36.5 & 17.3 & 35.4 & 4.3 & 3.1 & 2.3 & 3.1 \\
\hline $3^{*} \sigma_{j}$ & 59.8 & 47.0 & 18.9 & 45.5 & 6.2 & 4.9 & 3.2 & 5.0 \\
\hline
\end{tabular}

values of the index are more sensitive to the assumption on substitution, the results are more affected by changes in the $\sigma_{j}$ 's in the European Union than in the United States, where the agricultural sector is less protected.

\section{Policy Implications}

The results of our comparison of tariff indexes and tariff reduction scenarios should be used with caution in policy analysis. Indeed, figures for year 2000 (i.e., Uruguay Round scenario in Tables 3, 4, and 5) do not give a proper image of trade restrictiveness of agricultural trade policy, especially in the European Union. The reason is that, for the purpose of comparison between scenarios, the world price was kept the same as in the initial (1995) situation. We did not account for policy changes either, such as the fall in intervention price for grains in the European Union, which has an effect on the level of tariffs (the entry price capped to 155 percent of the intervention price). In addition, the actual protection of EU agriculture is clearly overestimated because we focused on the MFN tariffs. That is, we ignore preferential tariffs, which account for roughly 50 percent of the value of EU imports. Imports under regional agreements face very small tariffs in general and in quota tariffs are around one-third of the MFN tariff in the European Union (see Bureau and Tangermann 2000).

However, the results make it possible to refine the analysis made by BFS of the impact of the Uruguay Round on market access. First, while the BFS results suggested that the Uruguay Round had led to a larger increase in market access in the European Union than in the United States, relative to the pre-Uruguay Round situation, the computation 
of the absolute level of the MTRI shows that access to the EU market is still far more restricted than to the U.S. market, at least for countries that do not benefit from preferential treatment. Second, while BFS looked at the aggregate level, our results show that this is the case for all GTAP commodities in aggregate (except plant-based fibers). The difference in market access level is particularly large for grains and meat but is still significant for those commodities that are protected by relatively high tariffs in the United States, such as dairy products and sugar.

Computing the absolute level of the MTRI-uniform tariff also leads to a dramatic reconsideration of the image of the relative rates of protection of the EU and U.S. agricultural sectors. Indeed, on a nonweighted basis, the overall average tariff on agricultural and food products was 26.7 percent in the European Union and 9.7 percent in the United States in 1995, while the trade-weighted average tariff was, respectively, 25.5 percent in the European Union and 3.3 percent in the United States. We earlier pointed out that a trade-weighted average tariff smaller than the nonweighted one can result from prohibitive tariffs, or may simply mean that larger tariffs are set on commodities whose demand is particularly elastic. However, the MTRI-uniform tariff measures a degree of trade restrictiveness of 32.4 percent for the European Union and 3.5 percent for the United States (see Tables 3 and 4). That is, the difference between the MTRI-uniform tariff and the nonweighted average tariff is much larger in relative terms (and of opposite sign) in the case of the United States than in the case of the European Union. This suggests that the high tariffs in the United States are on a restricted set of very particular goods, most of them being imported in small quantities. In fact, very high tariffs are concentrated on specific types of processed food (e.g., peanuts, preparations with meat, or processed vegetables). High tariffs are also set on dairy products, but the bulk of imports that accounts for large import values, namely tropical products and live animals, faces almost zero tariffs. In contrast, in the EU most of the commodities imported in large quantities face significant tariffs, at least under MFN treatment. 


\section{Conclusion}

We provided a summary measure of the Uruguay Round tariff reduction commitments in the European Union and United States, taking into account the impact of changes in a large number of tariff lines. We also evaluated the impacts of alternative tariff-cutting procedures, using the MTRI as the tariff aggregator. Under the assumptions presented in the paper, the MTRI is the correct way to measure the consequences of tariff barriers on the volume of imports.

We were able to compute the index for particular commodity aggregates without using a CGE model but we assumed a specific functional form for import demand. Such an approach is easy to implement, as it requires only information on tariffs, import values, and total expenditure on each commodity (in addition to the knowledge of the parameters of the import demand function). The results are not only interesting as summary statistics on tariff protection but they could also be used to feed information into more aggregated models.

On the methodological side, the MTRI-uniform tariff and the trade-weighted index tend to move closely together when the number of commodities is small (e.g., paddy rice), and when the dispersion of tariffs is low. In other cases, the trade-weighted index underestimates the true impact of the tariff structure on market access, as measured by the MTRI. When we aggregate a large number of tariffs (e.g., the case of dairy products and vegetables both in the United States and in the European Union), or when the dispersion is large (e.g., the case of oilseeds in the United States, animals in the European Union), the two indexes differ significantly.

The difference that we observe between the MTRI and the nonweighted tariff average suggests that CGE or trade models that rely on aggregate tariffs constructed as simple averages use poor estimates of the actual tariff structure. This bias is likely to affect a large number of studies, as it is common practice to construct aggregate tariffs as simple averages of the detailed tariffs applied by custom officers, who sometimes work at a level of detail corresponding to the HS 10- or HS 12-digit level (in the case of the European Union). Constructing the aggregate tariffs used in CGE or trade models as trade-weighted averages is obviously more satisfactory. However, when aggregating a large number of goods with a large tariff dispersion into a single commodity, this 
method also results in significant bias, usually an underestimation of the aggregate tariff, as measured by the MTRI.

The computation of the absolute levels of the index makes it possible to compare the strategies in the allocation of tariff reductions taking into account the difference in the initial (bound) tariffs of the European Union and United States. We were also able to assess the consequences of emphasizing reductions in tariff dispersion in terms of getting a (more) level playing field between the European Union and the United States. Overall, our results confirm the intuition by BFS: although the "dilution" of tariff cuts has a limited impact on market access overall, the latter would be increased significantly if most protected commodities were subject to larger tariff cuts. 


\section{Endnotes}

1. BFS simulate the situation after the Uruguay Round implementation period if countries had not allocated tariff reductions between tariff lines in a strategic way in order to meet the objective of an average 36 percent reduction (see BFS 2000). That is, they simulate the effect of a 36 percent decrease in each tariff in the food and agricultural sector.

2. The balance of trade function summarizes the outcome of the consumption sector, the production sector, and the public behavior by including tariff revenues in the trade expenditure function. Equilibrium of the economy is consistent with a balance of trade that equals an exogenous income. Anderson and Neary (1996) and Martin (1997) provide detailed insights on the use of the balance-of-trade function.

3. Anderson and Neary (1999) use Anderson's (1998) CGE model, which is unusually disaggregated as far as the trade structure is concerned. However, even this model relies on 4-digit Harmonized System of classification, while the official WTO tariff commitments of the European Union and the United States in the food and agricultural sector specify tariffs at the 8-digit level.

4. More generally, Neary (1998) shows how the failure to select a reference untaxed good leads to misleading results in the theory of trade policy.

5. Because we use the initial total expenditure $e_{j}^{0}$, the uniform tariff equivalent $\tau_{j}$ is only an approximation of the true general equilibrium measure since it ignores the change in tariff revenue.

6. Bach and Martin (2001) discuss the different tariff aggregators that should be used in different components of a CGE model.

7. The nonweighted average tariffs that are presented here differ significantly from those computed by Gibson et al. (2001), even though we use the same initial tariff data, i.e., the WTO schedules. The main difference lies in the convention for converting specific tariffs into ad valorem equivalents. We use a four-year average of unit values of either imports or exports (when imports are small or inexistent) at the 8-digit level, while Gibson et al. use world prices at a more aggregated level. We believe that with our convention, we minimize the risk of constructing artificial tariff peaks, which is often the case when one converts specific tariffs into ad valorem using reference prices for more aggregated commodities. It is also worth recalling that the U.S. schedule includes specific tariff lines for in-quotas tariffs (in the case of commodities subject to a tariff rate quota). These tariff lines were excluded from our analysis.

8. More precisely, Anderson and Neary proved the following proposition: "The MTRI-uniform tariff exceeds the trade-weighted average tariff if: (i) the compensated arc elasticity of demand for the composite tariffed good exceeds one; (ii) the composite tariffed good is normal; and (iii) the trade expenditure function is implicitly separable in tariffed and other goods" (Anderson and Neary 1999).

9. It should be recalled that BFS assume a linear import demand function and a diagonal import elasticities matrix. 


\section{Appendix}

\section{Proofs of Propositions}

Proof of Proposition 1. With all domestic prices equal to 1 in the base equilibrium, equation (10) becomes

$$
\sum_{i} p_{i j}^{*} \beta_{i j} \frac{1}{\left(\beta_{d j}\left(p_{d j}\right)^{1-\sigma_{j}}+\sum_{i} \beta_{i j}\left(p_{i j}^{*}\left(1+\tau_{j}\right)\right)^{1-\sigma_{j}}\right)\left[p_{i j}^{*}\left(1+\tau_{j}\right)\right]^{\sigma}}=\sum_{i} p_{i j}^{*} \beta_{i j} .
$$

When $\sigma_{j}=1$, the MTRI-uniform tariff equivalent is

$$
\tau_{j}=\frac{1-\beta_{d j}}{\sum_{i} \beta_{i j} p_{i j}^{*}}-1
$$

Recalling that in the base equilibrium $p_{i}^{*}=\frac{1}{1+t_{i}}$, from the above equation we obtain

$$
\tau_{j}=\frac{\sum_{i} \beta_{i j} t_{i j}}{\sum_{i} \beta_{i j}}
$$

This proves the proposition.

Proof of Proposition 2. We first write equation (10) as follows (dropping the $j$ index for the sake of simplicity)

$$
\sum_{i} p_{i}^{*} \beta_{i}\left(\frac{P^{\tau}}{p_{i}^{*}(1+\tau)}\right)^{\sigma} e^{0}-\sum_{i} p_{i}^{*} I_{i}^{0}=F(\tau, \sigma)=0
$$

Assuming that there is a solution $F\left(\tau^{0}, \sigma^{0}\right)=0$ and $F_{\sigma}\left(\tau^{0}, \sigma^{0}\right) \neq 0$, then by the Implicit Function Theorem in the neighborhood of $\left(\tau^{0}, \sigma^{0}\right)$ there exists a function $\tau^{0}=f\left(\sigma^{0}\right)$ and

$$
\frac{d \tau}{d \sigma}=-\left.\frac{F_{\tau}}{F \sigma}\right|_{\tau=f(\sigma)}
$$


The derivatives of the $\mathrm{F}$ function are $F_{\tau}<0, F_{\sigma}>0$. Indeed

$$
F_{\tau}=-\sigma \frac{e^{0}}{(1+\tau)^{2}} \sum_{i} \beta_{i}\left(\frac{P^{\tau}}{p_{i}^{*}(1+\tau)}\right)^{\sigma-1},
$$

which is negative;

$$
F_{\sigma}=\sum_{i} e^{0} \beta_{i} p_{i}^{*}\left(\frac{P^{\tau}}{(1+\tau)}\right)^{\sigma} \ln \left(\frac{P^{\tau}}{(1+\tau)}\right)
$$

and is positive since

$$
\left(\frac{P^{\tau}}{(1+\tau)}\right) \rightarrow 0 \Rightarrow\left(\frac{P^{\tau}}{(1+\tau)}\right)^{\sigma} \ln \left(\frac{P^{\tau}}{(1+\tau)}\right) \rightarrow 0 \text { and } \sigma>0 .
$$

Because the derivatives have opposite signs, $\tau$ increases with $\sigma$ (at least in the case where there exists a solution). Recalling from Proposition 1 that the MTRI and the trade-weighted average tariff coincides for $\sigma=1$, the result follows immediately.

All this is illustrated in Figure A.1, drawn in the space of uniform tariff $\tau$ and elasticity of substitution $\sigma$. The trade-weighted average tariff, which corresponds to point $A$, is drawn as a straight line, as it does not change according to the vale of the elasticity of substitution. To prove the theorem, we need to locate relative to $A$ the points corresponding to the MTRI-uniform tariff. They lie on the locus $F^{0}$, which from the previous results must be upward sloping. At point $B$, which corresponds to $\sigma=1$, we know from Proposition 1 that $\tau$ must be equal to the trade-weighted average tariff. The proposition follows immediately by inspection.

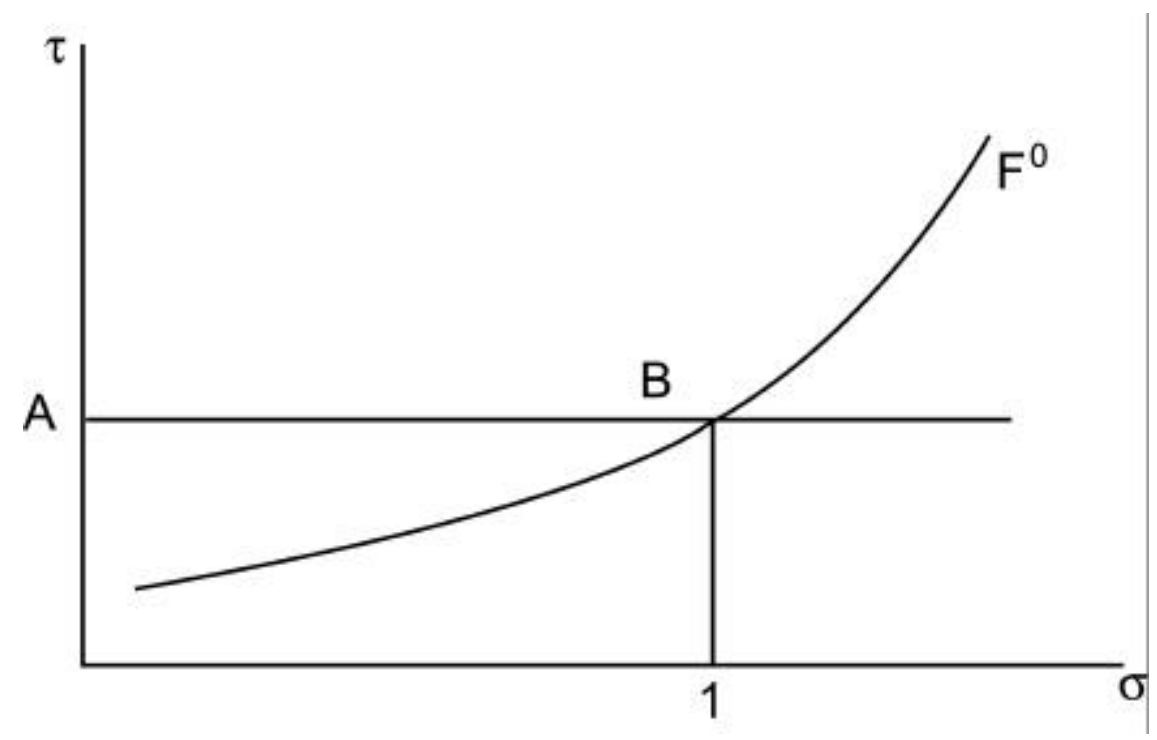

FIGURE A.1. Sensitivity of the uniform equivalent tariff to the elasticity of substitution 


\section{References}

Anderson, J.E. 1998. “Trade Restrictiveness Benchmarks.” The Economic Journal 108: 1111-25.

Anderson, J.E., and J.P. Neary. 1999. “The Mercantilistic Index of Trade Policy.” NBER Working Paper Series, 6870 (revised June 14, 2000), National Bureau of Economic Research, Cambridge, MA.

Anderson, J.E., and J.P. Neary. 1996. "A New Approach to Evaluating Trade Policy." Review of Economic Studies 63: 107-25.

Armington, P.A. 1969. “A Theory of Demand for Products Distinguished by Place of Production.” International Monetary Fund Staff Papers, 16, pp. 159-76.

Bach, C.F., and W. Martin. 2001. "Would the Right Tariff Aggregator Please Stand Up?" Journal of Policy Modelling. Forthcoming.

Bagwell, K., and R.W. Staiger. 2000. "GATT-Think.” NBER Working Paper, W8005. National Bureau of Economic Research, Cambridge, MA.

Brooke, A., D. Kendrick, A. Meeraus, and R. Raman. 1998. GAMS, A User's Guide. GAMS Development Corporation, Washington, D.C.

Bureau, J.C., L. Fulponi, and S. Salvatici. 2000. "Comparing EU and US Trade Liberalisation under the Uruguay Round Agreement on Agriculture.” European Review of Agricultural Economics 27(3): 1-22.

Bureau, J.C., and S. Tangermann. 2000. “Tariff Rate Quotas in the European Union.” Agricultural and Resources Economic Review 29(1, April): 70-80.

Gibson, P., J. Wainio, D. Whitley, and M. Bohman. 2001. "Profiles of Tariffs in Global Agricultural Markets." USDA Agricultural Economic Report 796, U.S. Department of Agriculture, Economic Research Service, Washington, D.C.

Hertel, T.W., E. Ianchivichina, and B.J. McDonald. 1997. "Multi-region General Equilibrium Modeling.” In Applied Methods for Trade Policy Analysis: A Handbook. Edited by J.F. Francois and K.A. Reinert. Cambridge, UK: Cambridge University Press, pp. 258-99.

Hertel, T.W., ed. 1997. Global Trade Analysis: Modeling and Applications. Cambridge, UK: Cambridge University Press.

Laird, S., and A. Yeats. 1988. "A Note on the Aggregation Bias in Current Procedures for the Measurement of Trade Barriers.” Bulletin of Economic Research 40(2): 134-43.

Martin, W. 1997. "Measuring Welfare Changes with Distortions." In Applied Methods for Trade Policy Analysis: A Handbook. Edited by J.F. Francois and K.A. Reinert. Cambridge, UK: Cambridge University Press, pp. 76-93. 
McDougall, R.A., A. Elbehri, and T.P. Truong. 1998. Global Trade Assistance and Protection: The GTAP 4 Data Base. Center for Global Trade Analysis, Purdue University.

Neary, J.P. 1998. "Pitfalls in the Theory of International Trade Policy: Concertina Reforms of Tariffs and Subsidies to High-Technology." Scandinavian Journal of Economics 100(1): 187-206. 